УДК 657.6:504.75

\title{
МЕТОДИЧНІ ЗАСАДИ ПОЖЕЖНОГО АУДИТУ ВИБУХОПОЖЕЖОНЕБЕЗПЕЧНИХ ОБ'ЄКТІВ
}

\author{
Азаров С.І ${ }^{1}$, Сидоренко В. ${ }^{2 *}$,, Сременко С.А ${ }^{2}$.Пруський А.В ${ }^{2}$, \\ ${ }_{1}^{1}$ Інститут ядерних досліджень Начіональної академії наук Украӥни \\ ${ }^{2}$ Інститут державного управління та наукових досліджень з изивільного захисту
}

\section{ІНФОРМАЦІЯ ПРО СТАТТЮ}

Надійшла до редакції:13.11.2020

Пройшла рецензування: 28.11.2020

кЛЮЧОВІ СЛОВА :

\section{пожежний аудит,}

вибухопожежонебезпечні об'єкти, технології геоінформаційних систем.

\begin{abstract}
АНОТАЦІЯ
Розглянуто методичні засади проведення пожежного аудиту вибухопожежонебезпечних об'єктів з метою попередження та запобігання пожеж та аварій на них. Зазначено, що потенціал пожежного аудиту для вибухопожежнонебезпечних об'єктів у повній мірі не реалізовано у зв'язку, насамперед, з відсутністю на даний час цього поняття у законодавчій і нормативноправовій базі та нового інструментарію для його проведення, а також дефіцитом політичної волі держави до послідовної практичної реалізації протипожежної політики з урахуванням рекомендацій Європейського Союзу. Підкреслено, що світовою практикою доведено доцільність і ефективність проведення пожежного аудиту. Визначено поняття пожежного аудиту та головні напрями протипожежної політики вибухопожежнонебезпечних об'єктів, а також процедуру, об'єкт, предмет, суть, види, типи пожежного аудиту та доступні методи його проведення. Обговорено вид, роль i переваги застосування технологій геоінформаційних систем в процедурі проведення пожежного аудиту вибухопожежнонебезпечних об'єктів. Застосовано метод оцінювання виконання протипожежних вимог підприємством. Показано, що сукупні техногенні ризики підприємства розглядають як суму ризиків промислових процесів. Наведено спосіб визначення ймовірності перевищення нормативного показника для двох спільних пожежних аспектів у разі врахування можливість прояву синергійного ефекту. Розглянуто спосіб оцінки виконання протипожежних вимог підприємством, техногенних ризиків, різноманітних пожежних аспектів певних процесів та очікуваного збитку у разі пожежі або аварії на вибухопожежнонебезпечних об'єктах. Розроблено алгоритм проведення контролю пожежонебезпечних параметрів на підприємстві та визначено порядок його використання. Запропоновано новий багатоетапний інструментарій проведення аудиту вибухопожежонебезпечних об'єктів із застосуванням технологій геоінформаційних систем. 3'ясовано значимість i подальше використання результатів i рекомендацій проведеного пожежного аудиту.
\end{abstract}

Постановка проблеми. Пожежний аудит (далі - ПА) вибухопожежонебезпечних об'єктів (далі ВПНО) [1,2] є важливим інструментом в системі національної безпеки країни. Щорічно на ВПНО відбуваються десятки купних пожеж і аварій, внаслідок який травмуються і гинуть люди та завдається збиток довкіллю. Але потенціал ПА для ВПНО у повній мірі не реалізовано у зв'язку, насамперед, з відсутністю на даний час цього поняття у законодавчій $\mathrm{i}$ 
нормативно-правовій базі та нового інструментарію для його проведення, а також дефіцитом політичної волі держави до послідовної практичної реалізації протипожежної політики з урахуванням рекомендацій ЄС.

Аналіз останніх досліджень i публікацій. Науковою проблематикою в галузі ПА ВПНО нині в нашій державі за причинами, наведеними вище, цікавляться небагато фахівців i науковців, але $\epsilon$ підтвердження необхідності його впровадження в практику [3-5], дослідження процедури оцінювання ризиків під час проведення аудиту [6] i навіть розглянуто його як додатковий інструмент державного регулювання пожежної безпеки в Україні [7].

Однак подальшим дослідженням, зокрема, такому як розроблення методичних засад проведення ПА ВПНО із застосуванням технологій географічних інформаційних системи (далі - ГІСтехнологій) в нашій країні достатньої уваги ще приділено не було.

Мета статті. Відповідно до зазначеної проблеми та, зокрема, виділеної нерозв'язаної раніше іiі частини, метою даного дослідження $\epsilon$ розробка методичних засад проведення ПА ВПНО. Для досягнення цієї мети необхідно визначити:

1) поняття ПА та головні напрями протипожежної політики ВПНО;

2) процедуру, об'єкт, предмет, суть, види, типи ПА та доступні методи його проведення;

3) роль і переваги застосування ГІСтехнологій в процедурі проведення ПА ВПНО;

4) спосіб оцінки виконання протипожежних вимог підприємством, техногенних ризиків, різноманітних пожежних аспектів певних процесів та очікуваного збитку у разі пожежі або аварії на ВПНО;

5) алгоритм проведення контролю пожежонебезпечних параметрів на підприємстві та алгоритм проведення ПА ВПНО;
6) новий
багатоетапний

інструментарій проведення ПА ВПНО;

7) значимість і подальше використання результатів і рекомендацій проведеного ПА.

Виклад основного матеріалу. ПА це систематичний, документально оформлений процес перевірки об'єктивно отриманих i оцінюваних аудиторських даних для визначення відповідності або невідповідності критеріям аудиту визначених видів протипожежної діяльності, умов, систем адміністративного управління або інформації щодо ВПНО, а також повідомлення оператору (пожежній організації) результатів, що отримані в ході цього процесу. Для забезпечення протипожежної безпеки i охорони навколишнього середовища під час експлуатації ВПНО в умовах ринкових відносин головними напрямами протипожежної політики є [3-5]:

наукове обгрунтування розміщення виробничих потужностей;

раціональне використання природних ресурсів (атмосферне повітря, земельні, водні, лісові надра, території видобування корисних копалин тощо);

негативний вплив діяльності ВПНО на довкілля;

удосконалення управління пожежної безпекою ВПНО (нафтобази, сховища газів, АЗС, артсклади, АЕС, ТЕС, ТЕЦ, звалища відходів і т.і.);

забезпечення пожежно-екологічно безпечного розвитку промисловості, сільського господарства, енергетики, транспорту і комунального господарства;

попередження пожеж та негативного впливу продуктів згоряння на довкілля;

швидка локалізація i ліквідація надзвичайних ситуацій природного i техногенного характеру;

забезпечення природного розвитку екосистем, збереження i відновлення унікальних природних комплексів під час вирішення протипожежних проблем.

Процедура ПА проводиться 3 метою проведення перевірки діяльності ВПНО в частині відповідності його діяльності діючому законодавству України у сфери цивільного захисту i розпорядженням 
органів ДСНС i МВС. Об'єктом ПА $\epsilon$ господарська та інша діяльність, в тому числі і минула, пов'язана 3 виникненням пожеж на ВПНО. Предметом ПА $\epsilon$ противопожежна профілактика, промислові, технічні, фінансові і правові аспекти діяльності, пов'язані з негативним впливом пожеж на ВПНО. Суть ПА полягає в тому, що аудит $\epsilon$ комплексним інструментом, здатним правильно оцінити фактори пожежної небезпеки i мінімізувати ризики функціонування ВПНО та їх подальшого стратегічного розвитку. Під час ПА ВПНО широко використовуються загальнонаукові i відповідні (специфічні) методи. До загальнонаукових методів належать: аналіз, синтез, індукція, дедукція, аналогія, моделювання, абстрагування, системний аналіз, функціонально-ціновий аналіз, причино наслідковий аналіз тощо. Специфічні методи ПА: метод пожежного балансу, метод експертних оцінок метод пожежно-економічних угрупувань, метод матеріальних балансів $\mathrm{i}$ технологічних розрахунків, оцінка протипожежного захисту i ефективності, профілактика, спостереження, інспекції, оцінки. 3 методами ПА пов'язані прийоми аудиторської перевірки (фото і відео зйомки, проведення натурних i лабораторних досліджень, інспектування виробничих об'єктів, аналіз документів, статистичне дослідження, тестування; прийоми економіко-математичних методів, логічна перевірка), які направлені на вирішення конкретної задачі на визначеному етапі використання методів. Методи організації ПА поділяються за методиками проведення перевірки (фактична і документальна) і за обсягом даних, що перевіряються (суцільна i вибіркова). Існують наступні види ПА: відповідності, управління, постачання, аудит нерухомості, поводження 3 горючими відходами, промислової території, енергопостачання, стратегічний аудит, страховий аудит, аудит накопичення збитків, інвестиційний аудит тощо.

Визначають наступні типи аудиторів: внутрішні аудитори - аудитори першої сторони (штатні співробітники підприємств); зовнішні аудитори аудитори другої сторони (співробітники організацій, зацікавлених в діяльності компанії, на якій проводиться аудит, наприклад, споживачі або інші особи від їх імені) та аудитори третьої сторони співробітники зовнішніх незалежних організацій, які проводять сертифікацію або реєстрацію на відповідність вимогам ICO 9001 або ICO 14001 [6].

Результатом ПА $є$ висновки (спостереження) аудиту як результат оцінки свідоцтв аудиту, що зібрані, на відповідність або невідповідність критеріям протипожежної безпеки i охорони навколишнього середовища під час експлуатації ВПНО або на можливість покращення та висновок за результатами аудиту у вигляді вихідних даних, представлених аудиторською групою після розгляду цілей і всіх висновків аудиту. На сучасному етапі для оцінювання пожежного стану різних об'єктів підвищеної небезпеки застосовують географічні інформаційні системи (далі ГІС). Однак існуючі ГІС-технології в повному обсязі не використовують під час проведення ПА ВПНО. Це пов'язано, насамперед, в першу чергу 3 особливостями проведення аудиту та невикористання ГІС як елемента системи контролю.

В даній роботі розглянуто можливість для проведення ПА ВПНО використовуючи ГІС-технології. Це дає можливість не тільки розв'язання аналітичних i прогнозних, статичних i динамічних задач, а також вибору форми видачі кінцевого результату (у картографічному, табличному, діаграмному виді), організацію діалогу 3 користувачем надаватимуть супровідними кількісними та якісними описами слоїв, а також збирати, аналізувати та моделювати ступінь протипожежного захисту ВПНО.

Особливістю запропонованої структурної схеми моделі проведення ПА ВПНО $\epsilon$ проведення пожежного моніторингу 3 використанням ГІСтехнологій, що дають змогу враховувати графічні матеріали контрольованих 
об'єктів і територій; чинники та джерела займання, рівні пожежного навантаження, топографічні карти місцевостей тощо. В існуючу виробничу систему контролю параметрів запропоновано впровадити певні пожежні сенсори для постійного моніторингу. Це дасть можливість у разі критичної зміни параметрів повідомляти керівництво для прийняття рішення щодо визначення елементів виробництва, що впливають на пожежний стан ВПНО. Для якісного врахування пожежного впливу необхідно сформувати критерії та показники ефективності, за якими буде здійснено оцінювання його негативного впливу на навколишнє середовище.

Результатами оцінювання пожежного стану ВПНО $є$ кількісна або якісна характеристика системи управління небезпечними промисловими процесами. Крім того, під час проведення аудиту підприємства виконують не тільки аналізування представленої динаміки зміни параметрів промислових процесів, але i обгрунтовують використання додаткових критеріїв та показників, що дають змогу повніше оцінювати ефективність всієї діяльності підприємства. Перш за все, необхідно удосконалити модель протипожежного управління. В основу моделі проведення ПА покладено визначення техногенних ризиків на підприємстві та використано принцип постійного моніторингу за технологічним промисловим циклом зі своєчасним втручанням в протипожежне управління підприємством для зниження рівня ризиків. Обов'язковою умовою для своєчасного втручання в систему протипожежного управління $є$ оцінювання пожежнонебезпечного стану ВПНО. Метою такого оцінювання $\epsilon$ збір необхідних даних про пожежній стан підприємства та їх аналізування для подальшої роботи системи в цілому. В цьому разі отримані дані вважають «початковими» або «встановленими», їх порівнюють 3 даними, отриманими в наступних часових періодах. Підприємство повинно здійснювати постійний моніторинг i контроль за вимірюванням основних параметрів тієї діяльності, що може чинити істотний вплив на пожежонебезпечний стан. Для оцінювання виконання протипожежних вимог підприємством здійснюють розрахунок за формулою:

$$
Q=\sum_{m=1}^{z} q_{m} h_{m},
$$

$\partial e, q_{m}-$ значимість вимог;

$h_{m}$ - ступінь виконання

протипожежних вимог підприємством; $m$ - кількість вимог.

Процедура оцінювання виконання протипожежних вимог підприємством має охоплювати всі сторони діяльності промислового процесу, починаючи 3 моменту надходження вибухових i горючих матеріалів i закінчуючи реалізацією готового продукту та всі аспекти, що так чи інакше можуть призводити до впливу на пожежну безпеку. Вони можуть стосуватися не тільки традиційних технологій, але i порядку інформування та навчання персоналу, взаємозв'язків із зовнішніми зацікавленими сторонами. Загальний перелік конкретних процедур, що підлягають документуванню, підприємство встановлює самостійно.

Пожежні показники характеризують процес виробництва, охоплює основну i допоміжну діяльність. Вони характеризують функціонування системи менеджменту та діяльність керівництва щодо поліпшення роботи всієї системи. Крім того, вони відображають інформацію про протипожежні умови або пожежонебезпечний стан ВПНО в поточний момент часу. В цьому разі сукупні техногенні ризики підприємства розглядають як суму ризиків промислових процесів (форм. 2)

$$
R=\sum_{i=1}^{n} R_{i}
$$

де, $R_{i}$ - ризик $i$-го процесу; $n$ - кількість процесів.

Під ризиком $i$-го процесу розуміють 
суму ризиків, пов'язаних 3 пожежними аспектами даного процесу (форм. 3)

$$
R=\sum_{j=1}^{L_{i}} r_{i j},
$$

$\partial e, r_{i j}-$ ризик $j$-го пожежного аспекту $i$-го процесу, $j=\overline{1, L_{i}}$; процесу.

$L_{i}$ - кількість пожежних аспектів $i$-го

При цьому ризик пожежного аспекту обчислюють (форм. 4)

$$
r_{i j}=p_{i j} \times u_{i j}
$$

де, $\quad p_{i j}-$ оцінка ймовірності перевищення нормативного показника для $j$-го пожежного аспекту $i$-го процесу;

$u_{i j}$ - оцінка збитку від перевищення нормативного показника впливи $j$-го пожежного аспекту $i$-го процесу.

При одночасному впливі на ВПНО декількох пожежонебезпечних процесів, необхідно враховувати можливість прояву синергетичного ефекту. У цьому випадку ймовірність перевищення нормативного показника для двох спільних пожежних аспектів можна розрахувати як:

$$
p_{i j}=p_{i l}+p_{i 2}-p_{i 1} \times p_{i 2} .
$$

Оцінку збитку від перевищення нормативного показника обчислюють як суму збитку вид пожежі. Загальний очікуваний збиток $Z_{o z}$ визначають (форм. 6).

$$
Z_{o z}=\sum_{j=1}^{v} Z_{j}
$$

de, $Z_{o z}$ - математичне очікування загального еколого-економічного збитку;

$Z_{j}$ - математичне очікування збитку за ризиком $j$-го пожежного аспекту.

Всі процедури, їх результати, дані моніторингу потрібно документувати. Запропонована модель діяльності у сфері протипожежного управління підприємством може здійснити запобігання пожежонебезпечного стану ВПНО на основі постійного моніторингу i контролю за пожежним станом. Основні економічні вигоди запобіганню пожеж та системному менеджменту визначаються різноманітними потенційними перевагами і додатковими можливостями, пов'язаними 3 подібною діяльністю. Результати проведення ПА повинні бути зведені в єдину базу даних, що дасть змогу відстежити та спрогнозувати поточну пожежонебезпечну ситуацію, а також надасть можливість представляти чіткі висновки та рекомендації щодо впливу підприємства на пожежну безпеку та відносно гармонійне функціонування ВПНО як складової частини регіону. На рис. 1 представлено узагальнену структурну схему алгоритму проведення контролю параметрів на підприємстві для оцінювання пожежонебезпечного стану.

$\begin{array}{ccr}\text { Підвищення } & \text { якості } & \text { системи } \\ \text { менеджменту } & \text { підприємства } & \text { можна }\end{array}$
здійснити внаслідок комплексування результатів від різних засобів пожежного спостереження і контролю за допомогою ГІС-технологий. Для здобуття об'єктивної інформації про стан та про рівень пожежної небезпеки підприємства необхідно мати надійні засоби та використовувати сучасні методи пожежного контролю. 


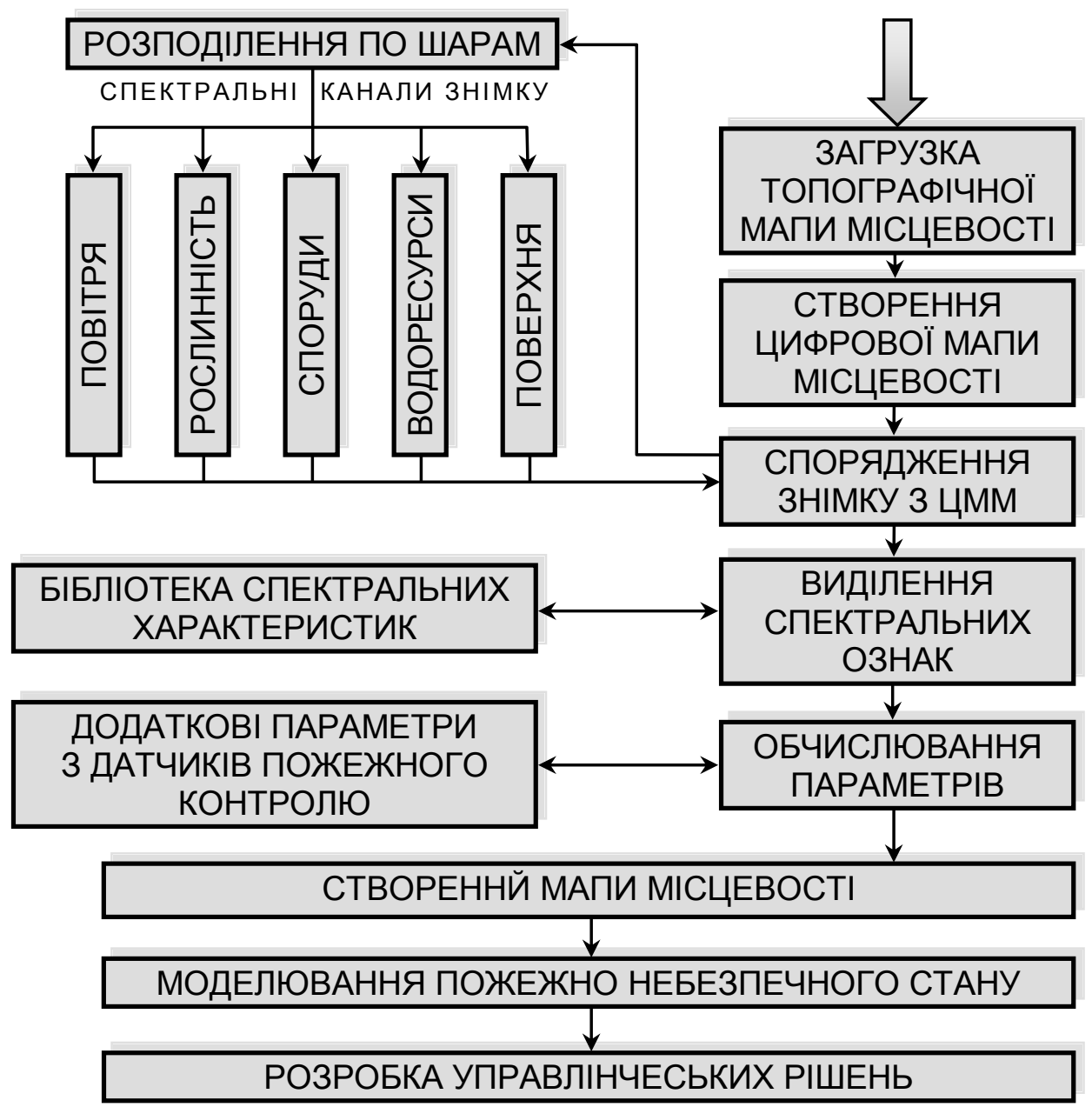

Рисунок 1 - Структурна схема алгоритму проведення контролю пожежонебезпечних параметрів на підприємстві

\section{1. ПІДГОТОВЧА РОБОТА}

(планування аудиту, формування команди, розподіл обов'язків та часу)

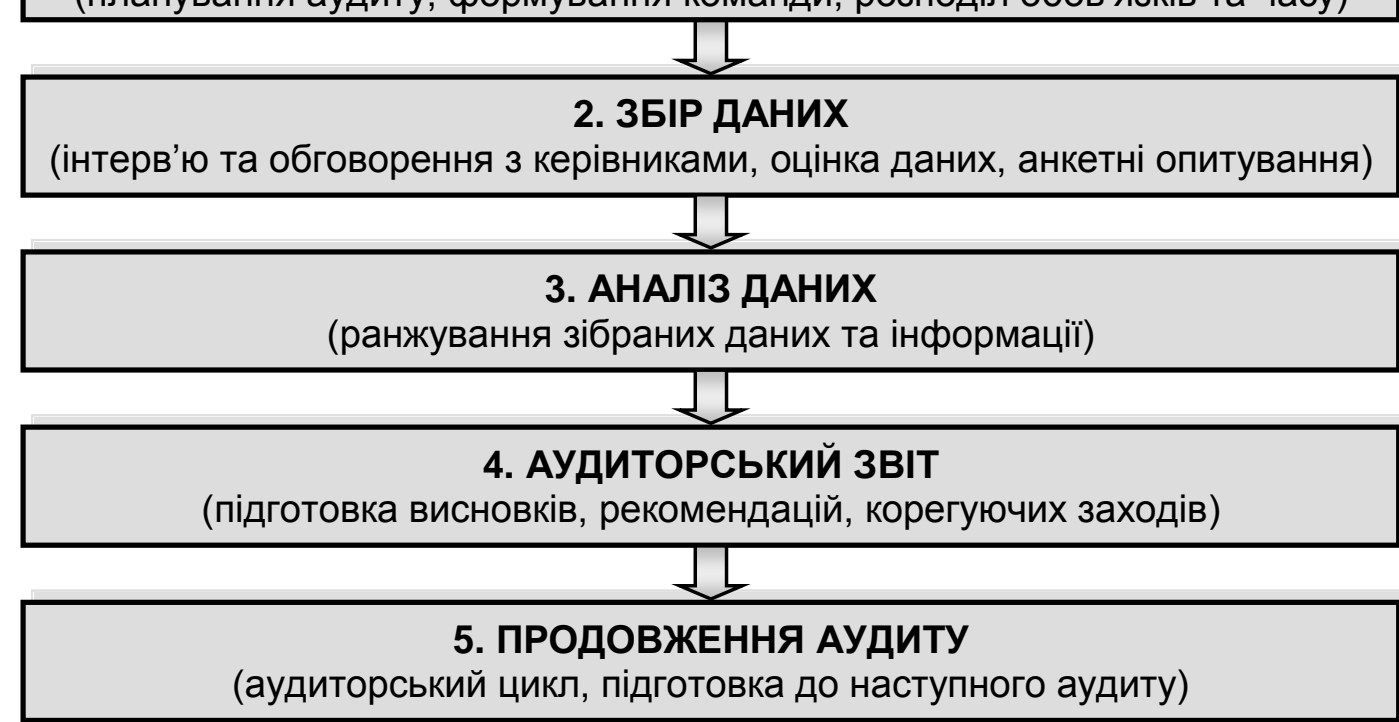

Рисунок 2 - Етапи проведення аудиту 
Для визначення необхідно порівнювати отримані результати з різних засобів контролю, у тому числі і дистанційних. А для підвищення об'єктивності отриманих результатів необхідно підвищення продуктивності, оперативності та регулярності вимірювань, збільшення масштабності охоплення одночасних технічних засобів контролю, а також автоматизація і оптимізація їх в промисловому процесі. Разом 3 традиційними методами контролю протипожежного захисту можливо використовувати дистанційні методи, що засновані на спектроскопії, яка використовує поглинання електромагнітного випромінювання у видимому та інфрачервоному областях спектру. Для підвищення якості проведення ПА промислових підприємств у роботі розроблено методику, особливістю якої $\epsilon$ використання ГІСтехнологій для проведення моніторингу i контролю за поточним пожежонебезпечного станом та врахування впливу промислових процесів підприємства на довкілля.

Аудиторський процес починається 3 ухвалення рішення про необхідність проведення ПА, що витікає 3 його можливості як одного 3 механізмів реалізації концепції стійкого розвитку. Саме це визначає його мету і завдання. Рішення приймається замовником. В цьому разі формування членів аудиторської комісії здійснюється на підборі провідних фахівців, які мають відповідну кваліфікацію і професійні знання, володіють методикою екологічної оцінки, практичний досвід роботи у відповідній сфері не менше певного періоду, а також сертифікат на право проведення екологічного аудиту. Робота комісії базується на принципах компетентності, досвідченості, об'єктивності, незалежності, відвертості, чесності, знання ВПНО. Фахівці повинні мати вищу освіту або спеціальні знання в проведенні екологічного аудитування об'єкту і їі геоекологічних особливостей не лише за документальною інформацією, але i за експериментальними даними.
Особливістю проведення екологічного аудиту $\epsilon$ те, що у разі потреби можливе залучення як консультантів висококваліфікованих фахівців інших сфер діяльності. Провідним методом роботи аудиторів $\epsilon$ експертна оцінка, що вважається в даний час загальнонауковою. Основою його $є$ дослідження і вирішення проблемних ситуацій професіоналами, які володіють спеціальними знаннями, шляхом вибору найбільш аргументованих рішень. Він застосовується, коли:

на підставі відомих законів неможливо однозначно передбачити поведінку системи у майбутньому;

неможлива

експериментальна перевірка передбачуваного ходу процесу;

$\epsilon$ невизначені чинники, що не піддаються контролю;

вирішення проблеми має багато варіантів;

інформація, на основі якої приймається рішення, недостатньо повна.

Крім того, в ході аудиторського дослідження використовуються також i певні наукові методи. У ході проведення аудиту підприємства збираються необхідні матеріали:

результати вибухопожежонебезпечних досліджень;

схеми генерального плану ВПНО і функціонального зонування території; ландшафтна карта;

існуючий емпіричний i картографічний матеріал, що характеризує грунти, повітря, воду;

дані комплексної оцінки геоекологічної ситуації підприємства в регіоні.

Структурно, алгоритм аудиту ВПНО повинен включати:

аналіз існуючої ситуації і вибір пріоритетних напрямів, де розпочнеться процес реалізації аудиту;

вибір та обгрунтування етапів;

навчання персоналу і фахівців;

оцінку результативності аудиту, включаючи зміну ставлення, поведінки та посилення економічної відповідальності за вплив на навколишне природне середовище;

інформування населення

та 
активізацію участі громадськості.

В цілому порядок проведення аудиту включає:

планування аудиту на основі попереднього аналізу організації оцінки масштабу майбутніх робіт, а також визначення процедури, що слід використовувати в процесі перевірки;

аналіз і оцінку системи обліку i звітності у галузі цивільного захисту, системи діючих та планованих превентивних заходів;

збір аудиторських доказів 3 метою оцінки відповідності діяльності економічного суб'єкта у сфері цивільного захисту, законодавчим i нормативним актам, а також перевірку їх достовірності;

документальне оформлення аудиторських доказів, виклад підсумків перевірки у вигляді аудиторського звіту і висновку.

Проведення ПА може бути представлено, як поетапний алгоритм, який залежно від специфіки ВПНО складається з наступних етапів (рис. 2)

Пропонується новий інструментарій проведення аудиту ВПНО, який складається з декількох етапів.

Передаудиторський етап:

ухвалення рішення про необхідність проведення ПА;

призначення аудиторської комісії та організація їі роботи;

визначення мети ПА, кола питань, що розглядатимуться під час проведення аудиту;

розробка протоколу аудиту (порядку його проведення на підставі певної мети, кола питань і вихідної інформації), що включає перелік вимог, підходів, процедур, яких повинні дотримуватись аудитори;

підготовка плану ПА, що включає три пункти: визначення персонального складу групи 3 розподілом функцій між іï членами, графік проведення аудиту; план організаційно-технічних заходів щодо проведення аудиту;

збори аудиторів у зв'язку з початком роботи (затвердження аудиторського колективу, розподіл обов'язків тощо);

робота зі збору інформації i встановлення загальних положень про об'єкт аудиту.

Проведення аудиту (аналітичний етап) як науково-практичного виду діяльності, що передбачає комплексну вибухопожежонебезпечну оцінку території 3 елементами аналізу, територіальної організації, а також метою вироблення заходів 3 iї стабілізації і забезпечення стійкого розвитку регіону. Висновки аудиторської діяльності знаходять своє відображення в звітній документації.

Eman аудиторської звітності. Підведення підсумків проведеної роботи та їх спільне обговорення:

список попередніх результатів;

завершальна нарада;

підготовка і подача звіту про аудит;

звіт перед замовником аудиту.

Проведення ПА може бути представлено, як:

1. Підготовча робота.

1.1. Постановка завдання ПА підприємства, мета та основні напрямки проведення. Побудова системи управління підприємством на основі розробленої моделі. В цьому разі вирішується завдання щодо пожежно-економічної оцінки. Відповідно до вимог стандартів ДСТУ ISO 14001:2006 та ДСТУ ISO 14001:2005 щодо ідентифікації та визначення важливіших напрямків ПА, перед підприємством виникає завдання оцінювання ступеня значимості і побудови рейтингу ПА.

1.2. Визначають критерії та ставлять багатокритеріальну задачу оцінювання значимості пожежних аспектів, що охоплює такі процедури:

1.2.1. Визначення для кожного критерію пожежного аспекту:

граничного параметру (фіксованих значень, що визначають вимоги, за яких один пожежний аспект перевершує інший);

типи змінних (чіткий кількісний, нечіткий кількісний, лінгвістичний);

цілі (максимізація - великі значення критерію краще менших, мінімізація менші значення краще великих).

1.2.2. Обчислення семантичної відстані (різниці між значеннями 
альтернатив);

1.2.3. Розрахунок ступеня переваги одного ПА над іншим щодо кожного критерію.

1.2.4. Розрахунок позитивного ефекту.

1.2.5. Розрахунок інформаційної складової відповідно зазначеного критерію.

1.2.6. Розрахунок позитивного i негативного потоків (визначення підсумкового ранжирування пожежного аспекту).

2. Робота щодо збору інформації про пожежонебезпечний стан підприємства.

Вибір методів збору інформації. Застосування методів та методик щодо отримання різних пожежонебезпечних характеристик про ВПНО.

Проводять збір даних під час проведення ПА на підприємстві 3 використанням ГІС-технологій та здійснюють контроль пожежонебезпечних параметрів та визначення його змін на основі проведення моніторингу. В цьому разі підприємство поділяється за шарами пожежонебезпечного стану та заповнюється отриманими параметрами.

3. Оцінка результатів.

На основі отриманих результатів проводять аналіз матеріалів ПА i розробляють висновок щодо підприємства.

3.1. Оцінюють ризики найбільш значущих пожежних аспектів.

Для аналізування значущих пожежонебезпечних процесів пропонується уточнення параметрів впливу пожежі на навколишнє середовище та за необхідності прогнозування надзвичайних ситуацій. Виявляють причини i джерела виникнення та перевищення нормативних значень пожежних аспектів, а також наслідки або несприятливі події, до яких вони можуть призвести. Після оцінювання ступеня значимості пожежної небезпеки стає зрозуміло, які пожежні аспекти потребують подальшого аналізування 3 точки зору уточнення ймовірності їх реалізації та розміру збитку.

3.2. Оцінюють ймовірність перевищення нормативних значень пожежного аспекту за допомогою логіко- імовірнісного методу.

На основі даних, отриманих у результат ПА, будують сценарії, що відображають причинно-наслідкові зв'язки між перевищеннями нормативного показника пожежі, джерелами та ініціювальними подіями. Оцінку ймовірності перевищення нормативного пожежного чинника розраховують за допомогою логіко-ймовірнісного методу, що охоплює такі етапи:

побудова функції алгебри логіки 3 використанням операцій кон'юнкції та диз'юнкції на основі сценаріїв перевищення впливів аспектів;

побудова імовірнісної функції на основі функції алгебри логіки;

розрахунок ймовірності перевищення нормативного пожежного показника за допомогою ймовірнісної функції.

3.3. Оцінюють імовірність перевищення нормативних значень пожежних аспектів на основі порівняння та визначення критичності.

3.4. Оцінюють екологічні збитки від перевищення негативного впливу пожежного чинника на навколишне середовище. Залежно від виду пожежного показника аспектів пропонується кілька варіантів оцінювання пожежонебезпечного стану ВПНО.

3.5. Оцінюють сукупний ризик підприємства від наслідків пожежі.

4. Оформлення звіту.

Оформлюють звіт для передавання його для вивчення керівництвом підприємства та подають пропозиції для подальшого використання їх щодо покращення системи менеджменту на підприємстві.

Аудиторська комісія може адресувати свої пропозиції до вищестоящих організацій та землекористувачам (землевласникам) цієї території в разі згоди замовника (окрім результатів обов'язкового зовнішнього аудиту).

Остаточні висновки, що фіксуються в аудиторському висновку, приймаються в ході спільного обговорення попередніх результатів аудиту i передаються замовникові. Разом 3 цим, аудит піднімає питання стратегічного розвитку як 
підприємства так і території регіону: розробка цільових програм, направлених на вирішення певних проблем, територіальних планів і схем розвитку, схем землекористування і тому подібне, тому результати аудиторської роботи за узгодженням із замовником можуть бути передані у відповідні вищестоящі інстанції. Оскільки замовник зацікавлений в аудиті, то питання примусовості реалізації висновків автоматично знімається. Він має право вільно розпоряджатися звітною документацією.

Отже, аудиторська комісія може виходити 3 рекомендаціями по організації механізму коадаптації в межах регіону i адресувати свої пропозиції вищестоящим організаціям не виходячи за рамки прямих інтересів замовника. Результати та рекомендації проведеного аудиту доводяться до місцевих органів влади, що повинні зробити оцінку поточного стану навколишнього середовища, розробити відповідні коригувальні заходи та здійснити запропоновані інструкції.

\section{Висновки}

\section{Ta}

напрями

подальшого дослідження. Таким чином, визначено, що завданням ПА $\epsilon$ пошук оптимальних шляхів поєднання економічного регулювання діяльності ВПНО. Встановлено, що його мета полягає у сприянні вчасному запобіганню соціального та економічного збитку, що виникають внаслідок впливу ВПНО на стан довкілля. Доведено, що результуючим показником аудиту $є$ надання достовірної та об'єктивної інформації, заснованої на ретельному аналізі численних факторів, що визначають міру співвідношення між економічною ефективністю експлуатації ВПНО та якістю навколишнього природного середовища. Показано, що ПА, як i будь-який вид діяльності, слід розглядати $з$ позицій системного підходу, у центрі якого знаходиться незалежна аудиторська компанія, що здійснює перевірку, аудитор або внутрішня служба підприємства, яка планує та реалізовує аудит.

3'ясовано, що аудит - це не тільки процес контролю за вкладанням капіталу у відтворення виробництва, а й універсальний інструмент, здатний мінімізувати негативний вплив на довкілля, сприяти ефективному використанню та відновленню природних ресурсів, а також підвищити інвестиційну привабливість ВПНО. Економічна оцінка процесів ПА дає можливість аудитору встановити контроль за використанням матеріально-технічних i природних ресурсів об'єкта аудиту і визначити рівень координованості та контрольованості складових системи менеджменту. Зазначено, що на основі застосування певних показників та їх взаємодії, а також необхідного обсягу даних, що отримуються в процесі проведення ПА, необхідно узгодити соціальні та економічні інтереси у суспільному виробництві.

Вважається доцільним під час проведення ПА ВПНО впроваджувати нові методики на основі застосування сучасних ГІС-технологій та методів нечіткого логічного висновку для управління в умовах невизначеності. На сьогоднішній день ГІС-технології дозволяють розглянути більш детальніше територію ВПНО за нормальної експлуатації та його впливу на навколишнє природне середовище, а також відслідковувати наслідки від пожеж і аварій.

Розроблено методичні засади проведення ПА ВПНО 3 метою попередження та запобігання пожеж та аварій на них.

Перспективи подальших досліджень автори бачать у більш глибокому i детальному опрацюванні зазначених етапів проведення ПА ВПНО.

\section{СПИСОК ВИКОРИСТАНИХ ДЖЕРЕЛ}

1. Про об'єкти підвищеної небезпеки : Закон України від 18.01.2001 р. № 2245-III / Верховна Рада України // Відомості Верховної Ради (ВВР). 2001. № 15. Ст. 73.

2. Про затвердження Положення про Державний реєстр потенційно небезпечних об'єктів : Постанова Кабінету Міністрів України від 29.08.2002 р. № 1288 / Кабінет Міністрів України // Офіційний 
вісник України. 2002. № 36. С. 43. Ст. 1694.

3. Кріса І. Я., Міллер О.В., Харчук А. І., Шелюх Ю. Є. Аудит з пожежної безпеки як альтернативна оцінка пожежного ризику об’єкта господарювання. Пожежна безпека: зб. наук. пр. 2011. № 19. C. $61-64$.

4. Харчук А. І., Міллер О. В. Аудит з пожежної безпеки як елемент управління пожежним ризиком. Проблеми ичивільного захисту: управління, попередження, аварійно-рятувальні та спеціальні роботи : зб. матер. II Всеукр. наук.-прак. конф. (25 жовт. 2013 р., м. Харків). Харків : НУЦЗУ, 2013. C. $69-72$.

5. Міллер О. В. Актуальність впровадження в практику пожежного аудиту. Розвиток цивільного захисту в сучасних безпекових умовах : матер. XVIII Всеукр. наук.-практ. конф. (за міжнар. уч.). Електронне видання комбінованого використання. (8 жовтня 2019 р., м. Київ,). Київ : ІДУЦЗ, 2019. C. $187-189$.

6. Дорош, Н. І. Оцінювання ризиків при проведенні аудиту. Науковий вісник національної академї статистики, обліку та аудиту. 2017. № 4. С. 40 - 46.

7. Андрієнко М. В. Напрями державного регулювання пожежної безпеки в Україні. Держава та регіони. Серія: Державне управління. 2017. № 3(59). С. 38 - 43.

8. Про перелік видів діяльності та об'єктів, що становлять підвищену екологічну небезпеку : постанова Кабінету Міністрів України від 27.07.1995 р. № 554. Офіиійиий вісник України. 1995. № 32. C. 132.

9. Про ідентифікацію та декларування безпеки об'єктів підвищеної небезпеки : постанова Кабінету Міністрів України від 11.07.2002 р. № 956. Офіиійний вісник Украӥни. 2002. № 29. С. 23. Ст. 1357.

10. Про затвердження Положення про паспортизацію потенційно небезпечних об'єктів : наказ МНС України від 18.12.2000 р. № 338. Офіційний вісник України. 2001. № 4. С. 345. Ст. 164.

11. Український класифікатор нормативних документів (ICS:2004, MOD) : ДК 004:2008. [Чинний від 2009-04-01]. Київ : Держспоживстандарт України, 2008. (Національний класифікатор України).

\section{REFERENCES}

1. Pro obiekty pidvyshchenoi nebezpeky : Zakon Ukrainy vid 18.01.2001 r. № 2245-III / Verkhovna Rada Ukrainy // Vidomosti Verkhovnoi Rady (VVR). 2001. № 15. St. 73 [in Ukrainian].

2. Pro zatverdzhennia Polozhennia pro Derzhavnyi reiestr potentsiino nebezpechnykh obiektiv : Postanova Kabinetu Ministriv Ukrainy vid 29.08.2002 r. № 1288 / Kabinet Ministriv Ukrainy // Ofitsiinyi visnyk Ukrainy. 2002. № 36. S. 43. St. 1694 [in Ukrainian].

3. Krisa, I. Ya., Miller O. V., Kharchuk A. I., Sheliukh Yu. Ye. Audyt z pozhezhnoi bezpeky yak alternatyvna otsinka pozhezhnoho ryzyku obiekta hospodariuvannia. Pozhezhna bezpeka: zb. nauk. pr. 2011. № 19. S. 61 - 64 [in Ukrainian].

4. Kharchuk, A. I., Miller O. V. Audyt z pozhezhnoi bezpeky yak element upravlinnia pozhezhnym ryzykom. Problemy tsyvilnoho zakhystu: upravlinnia, poperedzhennia, avariino-riatuvalni ta spetsialni roboty : zb. mater. II Vseukr. nauk.-prak. konf. (25 zhovt. 2013 r., m. Kharkiv). Kharkiv : NUTsZU, 2013. S. $69-72$ [in Ukrainian].

5. Miller, O. V. Aktualnist vprovadzhennia v praktyku pozhezhnoho audytu. Rozvytok tsyvilnoho zakhystu v suchasnykh bezpekovykh umovakh : mater. XVIII Vseukr. nauk.-prakt. konf. (za mizhnar. uch.). Elektronne vydannia kombinovanoho vykorystannia. (8 zhovtnia 2019 r., m. Kyiv,). Kyiv : IDUTsZ, 2019. S. 187 - 189 [in Ukrainian].

6. Dorosh, N. I. Otsiniuvannia ryzykiv pry provedenni audytu. Naukovyi visnyk natsionalnoi akademii statystyky, obliku ta audytu. 2017. № 4. S. 40 - 46 [in Ukrainian].

7. Andriienko, M. V. Napriamy derzhavnoho rehuliuvannia pozhezhnoi bezpeky v Ukraini. Derzhava ta rehiony. Seriia: Derzhavne upravlinnia. 2017. № 3(59). S. 38 - 43 [in Ukrainian].

8. Pro perelik vydiv diialnosti ta obiektiv, shcho stanovliat pidvyshchenu ekolohichnu nebezpeku : Postanova Kabinetu Ministriv Ukrainy vid 27.07.1995 r. № 554. Ofitsiinyi visnyk Ukrainy. 1995. № 32. S. 132.

9. Pro identyfikatsiiu ta deklaruvannia bezpeky obiektiv pidvyshchenoi nebezpeky : Postanova Kabinetu Ministriv Ukrainy vid 11.07.2002 r. № 956. Ofitsiinyi visnyk Ukrainy. 2002. № 29. S. 23. St. 1357 [in Ukrainian].

10. Pro zatverdzhennia Polozhennia pro pasportyzatsiiu potentsiino nebezpechnykh obiektiv : nakaz MNS Ukrainy vid 18.12.2000 r. № 338. Ofitsiinyi visnyk Ukrainy. 2001. № 4. S. 345 . St. 164 [in Ukrainian].

11. Ukrainskyi klasyfikator normatyvnykh dokumentiv (ICS:2004, MOD) : DK 004:2008. [Chynnyi vid 2009-04-01]. Kyiv : Derzhspozhyvstandart Ukrainy, 2008. (Natsionalnyi klasyfikator Ukrainy) [in Ukrainian]. 


\title{
METHODICAL BASES OF FIRE AUDIT OF EXPLOSIVE OBJECTS
}

\author{
S.Azarov $^{1}$, S. Yeremenko ${ }^{2}$, A. Pruskyi ${ }^{3}$, V.Sydorenko ${ }^{3}$ \\ ${ }^{1}$ Institute for Nuclear Research, National Academy of Sciences of Ukraine \\ ${ }^{2}$ Institute of Public Administration and Research in Civil Protection

KEYWORDS ANNOTATION

fire audit,

explosive objects,

technologies of

geographic

Methodical principles of conducting fire audit of explosive objects with the purpose of prevention of fires and accidents on them are considered. It is noted that the potential of fire audit for explosive objects is not fully realized in connection with, first of all, the lack of this concept in the legislative and regulatory framework and new tools for its implementation, as well as the lack of political will of the state to the consistent practical implementation of fire policy, taking into account the recommendations of the European Union. It is emphasized that the world practice has proved the information feasibility and effectiveness of a fire audit. The concept of fire audit and the main directions of fire policy of explosive objects, as well as the procedure, object, subject, essence, types of fire audit and available methods are conducted. The type, role and advantages of application of geographic information systems technologies in the procedure of fire audit of explosive objects are discussed. The method of assessment of fulfillment of fire safety requirements by the enterprise is applied. It is shown that the total man-made risks of the enterprise are considered as the sum of the risks of industrial processes. The method of determining the probability of exceeding the norm for two common fire aspects in case of taking into account the possibility of a synergistic effect. The method of assessing the implementation of fire safety requirements of the enterprise, man-made risks, various fire aspects of certain processes and the expected damage in case of fire or accident at explosive facilities is considered. The algorithm of control of fire-hazardous parameters at the enterprise is developed and the order of its use is defined. A new multi-stage toolkit for auditing explosive objects with the use of geographic information systems technologies is proposed. The significance and further use of the results and recommendations of fire audit were clarified.

\section{МЕТОДИЧЕСКИЕ ОСНОВЫ ПОЖАРНОГО АУДИТА ВЗРЫВООПАСНЫХ ОБЪЕКТАХ}

\section{С. Азаров 1 ., В. Сидоренко ${ }^{2}$., С. Еременко ${ }^{2}$., А. Прусский ${ }^{2}$}

${ }^{1}$ Институт ядерных исследований Национальной академии наук Украины

${ }^{2}$ Институт государственного управления и научных исследований по гражданской защите КЛЮЧЕВЫЕ СЛОВА АННОТАЦИЯ

пожарный аудит, Рассмотрены методические основы проведения пожарного аудита

взрывопожароопасные взрывопожароопасных объектов с целью предупреждения и

объекты, технологии

геоинформационных систем. предотвращения пожаров и аварий на них. Отмечено, что потенциал пожарного аудита для взрывопожароопасных объектов в полной мере не реализован в связи прежде всего с отсутствием в настоящее время это понятие в законодательной и нормативно-правовой базе и нового инструментария для его проведения, а также дефицитом политической воли государства к последовательной практической реализации противопожарной политики с учетом рекомендаций Европейского Союза. Подчеркнуто, что мировой практикой доказана целесообразность и эффективность проведения пожарного аудита. Определено понятие пожарного аудита и главные направления противопожарной политики взрывопожароопасных объектов, а также процедуру, объект, предмет, суть, виды, типы пожарного аудита и доступные методы его проведения. Обсуждены вид, роль и преимущества применения технологий геоинформационных систем в процедуре проведения пожарного аудита взрывопожароопасных объектов. Применен метод оценки выполнения противопожарных требований предприятием. Показано, что совокупные техногенные риски предприятия рассматривают как сумму рисков промышленных процессов. Приведены способ определения вероятности превышения нормативного показателя для двух совместных пожарных аспектов в случае учета возможность проявления синергетического эфрфекта. Рассмотрен способ оценки выполнения противопожарных требований предприятием, техногенных рисков, различных пожарных аспектов определенных процессов и ожидаемого ущерба в случае пожара или аварии на взрывопожароопасных объектах. Разработан алгоритм проведения контроля пожароопасных параметров на предприятии и определен порядок его использования. Предложен новый многоэтапный инструментарий проведения аудита взрывопожароопасных объектов с применением технологий геоинформационных систем. Выяснено значимость и дальнейшее использование результатов и рекомендаций проведенного пожарного аудита. 